\title{
Character Association and Path Analysis for Yield Components in Traditional Rice (Oryza sativa L.) Genotypes
}

\author{
Chandan Kishore ${ }^{1 *}$, Anil Kumar ${ }^{1}$, Awadhesh K. Pal ${ }^{2}$, Vinod Kumar ${ }^{3}$, \\ B.D. Prasad ${ }^{3}$ and Anand Kumar ${ }^{1}$ \\ ${ }^{1}$ Department of Plant Breeding and Genetics, ${ }^{2}$ Department of Biochemistry and Crop \\ Physiology, ${ }^{3}$ Department of Molecular Biology and Genetic Engineering, Bihar Agricultural \\ University, Sabour, Bhagalpur-813210, India
}

*Corresponding author

\section{A B S T R A C T}

The experiment was conducted in randomized block design replicated thrice, for the evaluation of thirteen quantitative traits in twenty rice genotypes. Significant difference for all the quantitative traits was observed among the genotypes indicating presence of

Keywords

PCV, GCV,

Heritability, Genetic

advance, Correlation,

Path analysis, Rice

Article Info

Accepted:

04 February 2018

Available Online:

10 March 2018 variability and scope of selection. Higher estimates of phenotypic coefficient of variation (PCV) than genotypic coefficient of variation (GCV) for all the traits reflected influence of environmental factor on these traits with variable influence. The characters fertile spikelet per panicles, Test weight, yield per plant, harvest index, Biological yield per plant and flag leaf width showed greater influence of environment reflecting scope of improvement of these traits by providing favourable environment whereas least influenced traits cannot be improved even in favourable condition but may be good for selection. The traits plant height, effective tillers per plant, flag leaf length, test weight and biological yield per plant showed high estimates of heritability and genetic advance implies additive genetic component and can be used for selection in early segregating generations. Considering both correlation and path study the traits Panicle length, biological yield per plant, harvest index and test weight showed true association with grain yield per plant having significant and positive correlation with high positive direct effect. Hence for implication of direct selection these traits should be considered.

\section{Introduction}

Rice (Oryza sativa L.) is the world's second most important cereal crop and about 90 per cent of the people of south-East Asia consume rice as staple food. Production of rice in India is low with respect to its demand and there is continuous need of varieties having high genetic potential in terms of yield and quality.
The study of genetic potential of a genotype is very useful for the development of high yielding verities. For this sound knowledge of existing genetic variability is essential. The large spectrum of genetic variability in segregating population depends on the amount of the genetic variability among genotypes and offer better scope for selection. The magnitude of heritable variation in the traits studied has 
immense value in understanding the potential of the genotype for further breeding programme. Assessment of variability for yield and its component characters becomes absolutely essential before planning for an appropriate breeding strategy for genetic improvement. Landraces harbour a great genetic potential for the improvement of desirable traits. Unlike high-yielding varieties (whose variability is limited due to homozygosity), the landraces maintained by farmers are endowed with tremendous genetic variability, as they are not subjected to subtle selection over a long period of time. This aids in the adaptation of landraces to wide agroecological niches and they also have unmatched qualitative traits and medicinal properties. This rich variability of complex quantitative traits still remains unexploited. The exact genetic potential, differences from commercial varieties, and the magnitude of heterogeneity still present in local landraces are not well catalogued. So, we formulated our research by taking fifteen land-races and five cultivated varieties of rice to know the nature and extent of genetic variability, association of traits with grain yield and their direct-indirect effect. Reports of many researchers has suggested that, the nature and magnitude of variation existing in available plant breeding materials is of obvious important for selection of desirable genotypes under planned breeding programme and yield improvement. Genetic parameters such as genotypic coefficient of variation $(\mathrm{GCV})$ and phenotypic coefficient of variation $(\mathrm{PCV})$ are useful in detecting the amount of variability present in the germplasm. Heritability coupled with high genetic advance would be more useful tool in predicting the resultant effect in selection of the best genotypes for yield and its attributing traits. It helps in determining the influence environment on the expression the genotypic and reliability of characters. Simultaneously, understanding the relationship between yield and its components is of paramount importance for making the best use of these relationships in selection. Character association derived by correlation coefficient, forms the basis for selecting the desirable plant, aiding in evaluation of relative influence of various component characters on grain yield. Path coefficient analysis discerns correlation into direct and indirect effects. Genotypic and different components of variance, heritability and genetic advance is always considered as a parameter for identification of genotypes having broad genetic variability and characters with high heritability to execute effective selection in rice and other crops.

\section{Materials and Methods}

Twenty rice genotypes were evaluated for thirteen quantitative traits in three replicated Randomized Block Design (RBD). Recommended dose of agronomic and plant protection measures were followed to raise a healthy crop. The data were recorded for days to $50 \%$ flowering (DFF), days to Maturity $(\mathrm{DM})$, plant height $(\mathrm{cm})(\mathrm{PH})$, effective tillers/ plant (ETP), flag leaf length $\mathrm{cm}$ (FLL), flag leaf width $\mathrm{cm}$ (FLW), chlorophyll content (CC), panicle Length $\mathrm{cm}$ (PL), fertile spikelets/ panice (FSP), test weight (gm) (TW), biological yield/ plant (BYP), harvest index (HI) and grain yield per plant (GYP). Chlorophyll content was recorded by chlorophyll meter (SPAD). Test of significance for each character were analyzed as per methodology advocated by Panse and Sukhatme (1967). Phenotypic coefficient of variation (PCV) and genotypic coefficient of variation (GCV) were calculated by the formula given by Burton (1952), heritability in broad Sense $\left(\mathrm{h}^{2}\right)$ by Burton and De Vane (1953) and genetic advance i.e. the expected genetic gain were calculated by using the procedure proposed by Johnson et al., (1955). The genotypic and phenotypic coefficient of correlation was calculated by adopting the 
method suggested by Singh and Chaudhary and path coefficient analysis was done as per method suggested by Dewey and Lu (1959).

\section{Results and Discussion}

A significant difference between multivariate traits is the pre-requisite for multivariate analysis and grouping of genotypes. It is further used in selection of the diverse parents for generation of desirable recombinants in segregating generation. In the present study, analysis of variance (ANOVA) (Table 1) revealed that, all the twenty rice genotypes significantly differed in respect of all quantitative traits. This shows the presence of considerable variability among the studied genotypes, suggesting the adequate scope for selection of superior genotypes aimed at enhancing yield potential of rice genotype.

Genetic parameters (Table 2) were studied to examine genetic worth of yield and related traits, based on genetic variability estimates viz., mean, range, phenotypic coefficient of variation (PCV), genotypic coefficient of variation $(\mathrm{GCV})$, heritability $\left(\mathrm{h}^{2}\right)$, genetic advance(GA) and genetic gain (GG). It was observed that all the character studied exhibited wide range of variation.

The most pronounced range of phenotypic variations was shown by plant height and a wide range was observed in fertile spikelet per panicle, biological yield per plant, days to fifty per cent flowering, days to maturity, test weight, flag leaf length, harvest index effective tiller per plant and yield per plant while narrow range was observed in flag leaf width and chlorophyll content. Higher estimates of phenotypic coefficient of variation than genotypic coefficient of variation for all the traits reflected influence of environmental factor on these traits with variable influence. The greater difference between GCV and PCV were observed for the characters fertile spikelet per panicles, Test weight, yield per plant, harvest index, Biological yield per plant and flag leaf width indicating that these characters influenced by environmental factors to a greater extent. The very little difference between GCV and PCV were indicated that there was very little environmental influence and these characters cannot be improved by providing favourable environmental condition. These findings are in agreement with earlier findings of Karad and Pol (2008), Akinwale et al., (2011).

Keeping in view that, consideration of heritability and genetic advance together prove more useful in predicting the resultant effect of selection on phenotypic expression (Johnson et al., 1955) five characters identified namely plant height, effective tillers per plant, flag leaf length, test weight and biological yield per plant.

These characters reflected greater contribution of additive genetic component may be exploited in selection in early segregating generations for the development of rice genotypes. The findings of Pal et al., (2011), Khriedinuo et al., (2011), Bharadwaj et al., (2007), Sarangi et al., (2009), Anjaneyulu et al., (2010) were in accordance with the present investigation.

Correlation analysis among yield and its contributing characters are shown in Table. 3 for clear understanding; correlation coefficients are separated into genotypic and phenotypic level. The genotypic correlation coefficients in most cases were higher than their phenotypic correlation coefficients indicating the genetic reason of association. In some cases phenotypic correlation coefficient were higher than genotypic correlation indicating suppressing effect of the environment which modified the expression of the characters at phenotypic level. 
Table.1 Analysis of variance for thirteen quantitative characters in rice genotypes

\begin{tabular}{|c|l|c|c|c|}
\multicolumn{5}{|c|}{ Sources of variation } \\
\hline S. No. & \multicolumn{1}{|c}{ Characters } & Replication $(\mathrm{df}=2)$ & Treatment $(\mathrm{df}=19)$ & Error $(\mathrm{df}=38)$ \\
\hline 1 & Days to 50\% flowering & 0.816 & $44.921^{* * *}$ & 1.658 \\
\hline 2 & Days to Maturity & 4.550 & $53.876^{* * *}$ & 2.707 \\
\hline 3 & Plant Height & 0.434 & $3009.047^{* *}$ & 3.871 \\
\hline 4 & Effective Tillers/ Plant & 1.600 & $85.762^{* *}$ & 0.625 \\
\hline 5 & Flag Leaf Length & 4.783 & $88.341^{* * *}$ & 2.668 \\
\hline 6 & Flag Leaf width & 0.009 & $0.065^{* *}$ & 0.007 \\
\hline 7 & Chlorophyll content & 1.784 & $12.415^{* * *}$ & 1.405 \\
\hline 8 & Panicle Length & 1.065 & $20.575^{* *}$ & 0.265 \\
\hline 9 & Fertile spikelets/ Panicles & 127.050 & $988.842^{* *}$ & 292.681 \\
\hline 10 & Test weight & 12.054 & $93.353^{* * *}$ & 5.332 \\
\hline 11 & Biological Yield/ Plant & 11.886 & $254.178^{* * *}$ & 11.176 \\
\hline 12 & Harvest Index & 9.857 & $51.027^{* * *}$ & 12.994 \\
\hline 13 & Grain Yield/ Plant & 1.183 & $15.829^{* * *}$ & 2.834 \\
\hline
\end{tabular}

Table.2 Estimation of mean, range, co-efficient of variation (PCV and GCV) heritability, genetic advance genetic gain and contribution \% for thirteen characters of twenty rice genotypes

\begin{tabular}{|c|c|c|c|c|c|c|c|c|c|}
\hline \multirow{2}{*}{$\begin{array}{l}\text { S. } \\
\text { No. }\end{array}$} & \multirow[t]{2}{*}{ characters } & \multirow[t]{2}{*}{ Mean } & \multicolumn{2}{|c|}{ Range } & \multirow[t]{2}{*}{ GCV\% } & \multirow[t]{2}{*}{ PCV\% } & \multirow{2}{*}{$\begin{array}{c}\mathbf{h}^{2}(\mathrm{bs}) \\
\%\end{array}$} & \multirow{2}{*}{$\begin{array}{c}\text { GA } \\
(5 \%)\end{array}$} & \multirow[t]{2}{*}{ GG $(5 \%)$} \\
\hline & & & Max. & Min. & & & & & \\
\hline 1 & $\begin{array}{l}\text { Days to } 50 \% \\
\text { flowering }\end{array}$ & 115.6 & 122.0 & 102.6 & 3.2 & 3.4 & 89.7 & 6.4 & 6.4 \\
\hline 2 & Days to Maturity & 147.8 & 150.0 & 130.3 & 2.7 & 3.0 & 86.3 & 7.9 & 5.3 \\
\hline 3 & Plant Height & 140.5 & 185.4 & 81.7 & 22.5 & 22.5 & 99.6 & 65.0 & 46.3 \\
\hline 4 & $\begin{array}{l}\text { Effective } \\
\text { Tillers/ Plant }\end{array}$ & 9.6 & 21.2 & 5.0 & 55.4 & 56.0 & 97.8 & 10.8 & 112.9 \\
\hline 5 & Flag Leaf Length & 28.1 & 39.4 & 20.8 & 18.9 & 19.8 & 91.5 & 10.5 & 37.3 \\
\hline 6 & Flag Leaf width & 1.4 & 1.7 & 1.2 & 9.8 & 11.6 & 72.2 & 0.2 & 17.2 \\
\hline$\overline{7}$ & $\begin{array}{l}\text { Chlorophyll } \\
\text { content }\end{array}$ & 38.9 & 43.3 & 34.9 & 4.9 & 5.7 & 72.3 & 3.3 & 8.6 \\
\hline 8 & Panicle Length & 24.5 & 30.4 & 19.2 & 10.5 & 10.7 & 96.2 & 5.2 & 21.3 \\
\hline 9 & $\begin{array}{l}\text { Fertile spikelets/ } \\
\text { Panicles }\end{array}$ & 108.0 & 133.6 & 77.6 & 14.1 & 21.2 & 44.2 & 20.8 & 19.3 \\
\hline 10 & Test weight & 28.1 & 36.6 & 16.4 & 19.2 & 20.9 & 84.6 & 10.2 & 36.4 \\
\hline 11 & $\begin{array}{l}\text { Biological } \\
\text { Yield/ Plant }\end{array}$ & 53.7 & 77.0 & 35.9 & 16.7 & 17.8 & 87.9 & 17.3 & 32.3 \\
\hline 12 & Harvest Index & 25.1 & 33.6 & 16.2 & 14.1 & 20.1 & 49.4 & 5.1 & 20.4 \\
\hline 13 & $\begin{array}{l}\text { Grain Yield/ } \\
\text { Plant }\end{array}$ & 13.2 & 18.2 & 8.5 & 15.7 & 20.2 & 60.4 & 3.3 & 25.2 \\
\hline
\end{tabular}

$\mathrm{GCV}=$ Genotypic coefficient of variation, $\mathrm{PCV}=$ Phenotypic coefficient of variation, $\mathrm{h}^{2}(\mathrm{bs})=$ Heritability (broad sense) $\mathrm{GA}=$ Genetic advance, $\mathrm{GG}=$ Genetic gain at $5 \%$. 
Table.3 Genotypic $(\mathrm{G})$ and phenotypic $(\mathrm{P})$ correlation coefficients for twelve quantitative characters in rice

\begin{tabular}{|c|c|c|c|c|c|c|c|c|c|c|c|c|c|c|}
\hline No & Characters & & DM & PH & ETP & FLL & FLW & $\mathrm{CC}$ & PL & FSP & TW & BYP & HI & GYP \\
\hline \multirow[t]{2}{*}{1} & \multirow[t]{2}{*}{ DFF } & $\mathbf{G}$ & $0.8093 * *$ & $0.3505 *$ & $-0.3091 *$ & $0.2826^{*}$ & $0.3692 * *$ & $-0.4182 * *$ & 0.1716 & 0.2437 & 0.2189 & -0.0039 & 0.1973 & 0.1416 \\
\hline & & $\mathbf{P}$ & $0.7240 * *$ & $0.3304 * *$ & $-0.2957 *$ & 0.2418 & $0.2818^{*}$ & -0.3875 & 0.1556 & 0.1730 & 0.1690 & -0.0247 & 0.1726 & 0.1216 \\
\hline \multirow[t]{2}{*}{2} & \multirow[t]{2}{*}{ DM } & $\mathrm{G}$ & & $0.5334 * *$ & $-0.4887 * *$ & 0.0599 & $0.2866^{*}$ & -0.2172 & $0.3350 * *$ & 0.2573 & $0.3559^{* *}$ & -0.1404 & $0.4437 * *$ & 0.1086 \\
\hline & & $\mathrm{P}$ & & 0.4998 & $-0.4383 * *$ & 0.0713 & $0.3046^{*}$ & -0.2028 & $0.3097 * *$ & 0.2132 & $0.3036^{*}$ & -0.0825 & $0.2785^{*}$ & 0.1421 \\
\hline \multirow[t]{2}{*}{3} & \multirow[t]{2}{*}{$\mathrm{PH}$} & $\mathrm{G}$ & & & $-0.9666 * *$ & $0.3405^{*}$ & $0.5837 * *$ & $-0.5407 * *$ & $0.7276 * *$ & -0.1510 & $0.7716^{* *}$ & 0.0333 & $0.5527 * *$ & $0.4356 * *$ \\
\hline & & $\mathrm{P}$ & & & $-0.9549 * *$ & $0.3247 *$ & $0.5015^{* *}$ & $-0.4500 * *$ & $0.7134 * *$ & -0.0894 & $0.7116^{* *}$ & 0.0280 & $0.3966^{* *}$ & $0.3446 *$ \\
\hline \multirow[t]{2}{*}{4} & \multirow[t]{2}{*}{ ETP } & G & & & & $-0.3286^{*}$ & $-0.4960 *$ & $0.5314 *$ & $-0.6928 *$ & 0.2144 & $-0.8434 * *$ & -0.1428 & $-0.4281 * *$ & $-0.4466 * *$ \\
\hline & & $\mathrm{P}$ & & & & $-0.3112 *$ & $0.4193 * *$ & $0.4499 * *$ & $-0.6745 * *$ & 0.1478 & $-0.7567 * *$ & -0.1277 & $-0.2875^{*}$ & $-0.3106^{*}$ \\
\hline \multirow[t]{2}{*}{5} & \multirow[t]{2}{*}{ FLL } & $\mathrm{G}$ & & & & & 0.2641 & $-0.5378 * *$ & $0.5737 * *$ & $-0.3851 * *$ & -0.0137 & 0.1396 & 0.0065 & 0.2262 \\
\hline & & $\mathrm{P}$ & & & & & 0.2277 & $-0.3675^{* *}$ & $0.5502 * *$ & $-0.2842 *$ & 0.0031 & 0.1328 & -0.0229 & 0.1209 \\
\hline \multirow[t]{2}{*}{6} & \multirow[t]{2}{*}{ FLW } & G & & & & & & $-0.2785^{*}$ & $0.3277^{*}$ & -0.1841 & $0.4009 * *$ & $-0.4461 * *$ & $0.7534 * *$ & 0.1619 \\
\hline & & $\mathrm{P}$ & & & & & & -0.1635 & $0.2708 *$ & -0.0668 & $0.3322 *$ & $-0.3258 *$ & $0.4269 * *$ & 0.1498 \\
\hline \multirow[t]{2}{*}{7} & \multirow[t]{2}{*}{$\mathrm{CC}$} & G & & & & & & & $-0.4086^{* *}$ & 0.1659 & $-0.3730 * *$ & $-0.5748 * *$ & 0.0983 & $-0.4970 * *$ \\
\hline & & $\mathrm{P}$ & & & & & & & $-0.3386 * *$ & 0.0641 & -0.2236 & $-0.4738 * *$ & 0.0693 & $-0.3795 * *$ \\
\hline \multirow[t]{2}{*}{8} & \multirow[t]{2}{*}{ PL } & G & & & & & & & & -0.0595 & $0.4651^{* *}$ & 0.0340 & $0.4861 * *$ & $0.4349 * *$ \\
\hline & & $\mathrm{P}$ & & & & & & & & -0.0318 & $0.4374 * *$ & 0.0206 & $0.3485^{*}$ & $0.3466^{*}$ \\
\hline \multirow[t]{2}{*}{9} & \multirow[t]{2}{*}{ FSP } & $\mathrm{G}$ & & & & & & & & & 0.1514 & 0.1543 & 0.0754 & 0.1311 \\
\hline & & $\mathrm{P}$ & & & & & & & & & -0.0056 & 0.1231 & 0.0517 & 0.1729 \\
\hline \multirow[t]{2}{*}{10} & \multirow[t]{2}{*}{ TW } & G & & & & & & & & & & $0.3349 * *$ & 0.1995 & $0.4058 * *$ \\
\hline & & $\mathrm{P}$ & & & & & & & & & & 0.2404 & 0.2214 & $0.3374 *$ \\
\hline \multirow[t]{2}{*}{11} & \multirow[t]{2}{*}{ BYP } & G & & & & & & & & & & & $-0.6312 * *$ & $0.4210 * *$ \\
\hline & & $\mathrm{P}$ & & & & & & & & & & & $-0.5311^{* *}$ & $0.3071 *$ \\
\hline \multirow[t]{2}{*}{12} & \multirow[t]{2}{*}{ HI } & $\mathrm{G}$ & & & & & & & & & & & & $0.4408 * *$ \\
\hline & & $\mathrm{P}$ & & & & & & & & & & & & $0.5404 * *$ \\
\hline
\end{tabular}

$\mathrm{DFF}=$ Days to $50 \%$ flowering, DM $=$ Days to Maturity, PH = Plant Height $\mathrm{cm}$, ETP $=$ Effective Tillers/ Plant, FLL = Flag Leaf Length $\mathrm{cm}$, FLW $=$ Flag Leaf width $\mathrm{cm}, \mathrm{CC}=$ Chlorophyll content, $\mathrm{PL}=$ Panicle Length $\mathrm{cm}, \mathrm{FSP}=$ Fertile spikelets $/$ Panicle, TW = Test weight gm, BYP = Biological Yield $/$ Plant, HI = Harvest Index, GYP = Grain yield per plant 
Table.4 Direct (diagonal values) and indirect effect of different characters on seed yield in rice at genotypic and phenotypic level

\begin{tabular}{|c|c|c|c|c|c|c|c|c|c|c|c|c|c|c|c|}
\hline No & Character & & DFF & DM & PH & ETP & FLL & FLW & $\mathrm{CC}$ & PL & FSP & TW & BYP & HI & GYP \\
\hline \multirow[t]{2}{*}{1} & \multirow[t]{2}{*}{ DFF } & $\mathbf{G}$ & 0.9265 & 0.7498 & 0.3247 & -0.2864 & 0.2618 & 0.3421 & -0.3875 & 0.1590 & 0.2258 & 0.2028 & -0.0036 & 0.1828 & 0.1416 \\
\hline & & $\mathbf{P}$ & -0.0919 & -0.0665 & -0.0303 & 0.0272 & -0.0222 & -0.0259 & 0.0366 & -0.0143 & -0.0159 & -0.0155 & 0.0023 & -0.0159 & 0.1216 \\
\hline \multirow[t]{2}{*}{2} & \multirow[t]{2}{*}{ DM } & G & -0.9388 & -1.1601 & -0.6188 & 0.5670 & -0.0695 & -0.3325 & 0.2520 & -0.3886 & -0.2985 & -0.4129 & 0.1628 & -0.5148 & 0.1086 \\
\hline & & $\mathrm{P}$ & 0.0077 & 0.0106 & 0.0053 & -0.0046 & 0.0008 & 0.0032 & -0.0021 & 0.0033 & 0.0023 & 0.0032 & -0.0009 & 0.0030 & 0.1421 \\
\hline \multirow[t]{2}{*}{3} & \multirow[t]{2}{*}{$\mathrm{PH}$} & G & -0.3568 & -0.5430 & -1.0180 & 0.9840 & -0.3467 & -0.5942 & 0.5504 & -0.7407 & 0.1537 & -0.7855 & -0.0339 & -0.5626 & 0.4356 \\
\hline & & $\mathrm{P}$ & -0.0806 & -0.1219 & -0.2439 & 0.2329 & -0.0792 & -0.1223 & 0.1098 & -0.1740 & 0.0218 & -0.1736 & -0.0068 & -0.0968 & 0.3446 \\
\hline \multirow[t]{2}{*}{4} & \multirow[t]{2}{*}{ ETP } & G & 0.9501 & 1.5021 & 2.9709 & -3.0734 & 1.0101 & 1.5243 & -1.6333 & 2.1292 & -0.6588 & 2.5920 & 0.4387 & 1.3158 & -0.4466 \\
\hline & & $\mathrm{P}$ & 0.0173 & 0.0256 & 0.0558 & -0.0584 & 0.0182 & 0.0245 & -0.0263 & 0.0394 & -0.0086 & 0.0442 & 0.0075 & 0.0168 & -0.3176 \\
\hline \multirow[t]{2}{*}{5} & \multirow[t]{2}{*}{ FLL } & G & -0.1807 & -0.0383 & -0.2178 & 0.2102 & -0.6396 & -0.1690 & 0.3440 & -0.3670 & 0.2463 & 0.0088 & -0.0893 & -0.0041 & 0.2262 \\
\hline & & $\mathrm{P}$ & 0.0161 & 0.0048 & 0.0217 & -0.0208 & 0.0668 & 0.0152 & -0.0245 & 0.0367 & -0.0190 & 0.0002 & 0.0089 & -0.0015 & 0.1209 \\
\hline \multirow[t]{2}{*}{6} & \multirow[t]{2}{*}{ FLW } & G & 0.1896 & 0.1472 & 0.2998 & -0.2547 & 0.1357 & 0.5136 & -0.1430 & 0.1683 & -0.0946 & 0.2059 & -0.2291 & 0.3870 & 0.1619 \\
\hline & & $\mathrm{P}$ & 0.0084 & 0.0090 & 0.0149 & -0.0124 & 0.0068 & 0.0297 & -0.0048 & 0.0080 & -0.0020 & 0.0099 & -0.0097 & 0.0127 & 0.1492 \\
\hline \multirow[t]{2}{*}{7} & \multirow[t]{2}{*}{$\mathrm{CC}$} & G & -0.3154 & -0.1639 & -0.4079 & 0.4008 & -0.4056 & -0.2100 & 0.7543 & -0.3082 & 0.1251 & -0.2813 & -0.4336 & 0.0741 & -0.4970 \\
\hline & & $\mathrm{P}$ & 0.0716 & 0.0364 & 0.0808 & -0.0807 & 0.0659 & 0.0293 & -0.1795 & 0.0608 & -0.0115 & 0.0401 & 0.0850 & -0.0124 & -0.3795 \\
\hline \multirow[t]{2}{*}{8} & \multirow[t]{2}{*}{ PL } & G & 0.0357 & 0.0698 & 0.1516 & -0.1443 & 0.1195 & 0.0683 & -0.0851 & 0.2083 & -0.0124 & 0.0969 & 0.0071 & 0.1013 & 0.4349 \\
\hline & & $\mathrm{P}$ & 0.0013 & 0.0026 & 0.0059 & -0.0056 & 0.0046 & 0.0022 & -0.0028 & 0.0083 & -0.0003 & 0.0036 & 0.0002 & 0.0029 & 0.3466 \\
\hline \multirow[t]{2}{*}{9} & \multirow[t]{2}{*}{ FSP } & G & 0.0941 & 0.0994 & -0.0583 & 0.0828 & -0.1488 & -0.0711 & 0.0641 & -0.0230 & 0.3864 & 0.0585 & 0.0596 & 0.0291 & 0.1311 \\
\hline & & $\mathrm{P}$ & 0.0105 & 0.0129 & -0.0054 & 0.0089 & -0.0172 & -0.0040 & 0.0039 & -0.0019 & 0.0605 & -0.0003 & 0.0074 & 0.0031 & 0.1729 \\
\hline \multirow[t]{2}{*}{10} & \multirow[t]{2}{*}{ TW } & G & -0.4712 & -0.7661 & -1.6610 & 1.8154 & 0.0295 & -0.8629 & 0.8029 & -1.0012 & -0.3259 & -2.1525 & -0.7210 & -0.4294 & 0.4058 \\
\hline & & $\mathrm{P}$ & 0.0030 & 0.0054 & 0.0126 & -0.0134 & 0.0001 & 0.0059 & -0.0040 & 0.0077 & -0.0001 & 0.0177 & 0.0042 & 0.0039 & 0.3374 \\
\hline \multirow[t]{2}{*}{11} & \multirow[t]{2}{*}{ BYP } & G & -0.0076 & -0.2743 & 0.0650 & -0.2790 & 0.2728 & -0.8718 & -1.1234 & 0.0664 & 0.3015 & 0.6546 & 1.9544 & -1.2336 & 0.4210 \\
\hline & & $\mathrm{P}$ & -0.0186 & -0.0621 & 0.0210 & -0.0962 & 0.1000 & -0.2454 & -0.3568 & 0.0155 & 0.0927 & 0.1810 & 0.7531 & -0.3999 & 0.3071 \\
\hline \multirow[t]{2}{*}{12} & \multirow[t]{2}{*}{ HI } & G & 0.2161 & 0.4860 & 0.6053 & -0.4689 & 0.0071 & 0.8252 & 0.1076 & 0.5324 & 0.0826 & 0.2185 & -0.6913 & 1.0953 & 0.4408 \\
\hline & & $\mathrm{P}$ & 0.1769 & 0.2854 & 0.4064 & -0.2945 & -0.0235 & 0.4374 & 0.0710 & 0.3571 & 0.0530 & 0.2269 & -0.5441 & 1.0245 & 0.5404 \\
\hline
\end{tabular}

DFF $=$ Days to $50 \%$ flowering, DM = Days to Maturity, PH = Plant Height $\mathrm{cm}$, ETP = Effective Tillers $/$ Plant, FLL = Flag Leaf Length cm, FLW = Flag Leaf width $\mathrm{cm}, \mathrm{CC}=$ Chlorophyll content, $\mathrm{PL}=$ Panicle Length $\mathrm{cm}, \mathrm{FSP}=$ Fertile spikelets $/$ Panicle, TW = Test weight gm, BYP = Biological Yield $/$ Plant, HI = Harvest Index, GYP = Grain yield per plant 
The grain yield per plant was highly significant and positively correlated with harvest index followed by plant height, biological yield per plant and test weight. The result is in accordance with the result of Basavaraja et al., (1997) for plant height, Chakraborty et al., (2001) for 1000 seed weight, Chaudhary and Motiramant (2003) for biological yield per plant Ramanjaneyulu et al., for harvest index reported similar results and results of Sarawgi (1996) supported the present result for both biological yield and harvest index. Chlorophyll content and effective tillers per plant has significant and negative correlation with grain yield per plant indicating that photosynthetic mobilization to grains is limited in the traditional photosensitive genotypes having good chlorophyll content and high effective tillers. The result is in the conformation with the result of Ghosh et al., (2003)

Plant height exhibited significant and positive correlation with flag leaf length and width, panicle length, test weight; harvest index and grain yield per plant whereas its significant and negative correlation was observed with effective tillers per plant, chlorophyll content and fertile spikelet per panicle at both genotypic and phenotypic level. The result reflecting that, taller plant have higher yield with bold seed and less no. of effective tillers, fertile spikelet per panicle and low value of total chlorophyll content. This result is in accordance with the result of Nayak et al., (2001), Prasad (2001) and Neeraj (2011)

Positive and significant correlation was observed between effective tillers per plant and flag leaf width at phenotypic level only (due environmental effects) whereas it showed Positive and significant correlation with chlorophyll content at both genotypic and phenotypic level. Negative and significant value for genotypic and phenotypic correlation was observed between effective tillers per plant and flag leaf length, panicle length, test weight, biological yield per plant, harvest index and grain yield per plant. Flag leaf width also reflected negative correlation with effective tillers per plant at genotypic level only. The result implies that, increase in effective tillers per plant, increases only chlorophyll content otherwise, it decreases the flag leaf length and width, panicle length, test weight, biological yield per plant, harvest index and grain yield per plant. This is in conformation with the result of Deepa Shankar et al., (2006) and Ravindra Babu et al., (2012).

Chlorophyll content has significant and negative value of correlation with panicle length, test weight, biological yield and grain yield per plant. This shows that, genotypes having long panicle length, higher test weight, higher biological yield and grain yield per plant have lower chlorophyll content and hence negligible contribution in sink development and inefficient in photosynthetic mobilisation to grain yield. This result is in contradiction to the results of Gosh et al., (2003) who worked on photo-insensitive varieties showing positive and significant correlation of chlorophyll content with yield confirming its role towards sink development. This may be due to the photo-sensitive nature of the genotypes under study. Panicle length has positive and significant value of correlation with test weight, biological yield and grain yield per plant which reveals that genotypes having longer panicle and higher test weight have higher yield. For test weight is concern, it is positively and significantly correlated with biological yield and grain yield per plant. Biological yield per plant and harvest index was positively correlated with yield whereas biological yield per plant was negatively associated with harvest index. The result is supported by the result of Suman (2003), Sankar et al., (2006) and Padmaja et 
al., (2011). The association of traits was further partitioned into direct and indirect effect provided actual information on the contribution of traits and thus forms the basis for selection to improve grain yield (Table 4). The highest direct positive effect was exhibited by Biological yield per followed by harvest index, days to fifty per cent flowering, chlorophyll content, flag leaf width, fertile spikelet per panicle and panicle length. Therefore, considering both correlation and path study the traits Panicle length, biological yield per plant, harvest index and test weight showed true association with grain yield per plant. Among these traits, panicle length showed positive indirect effect via plant height, flag leaf length and harvest index. Likewise biological yield per plant has indirect effect with test weight, fertile spikelet per plant and flag leaf length. For Harvest index, flag leaf width, plant height, panicle length, days to maturity, test weight, days to fifty per cent flowering and chlorophyll content were indirectly contributing the yield per plant. Test weight showed indirect positive effect via effective tillers per plant and chlorophyll content. Hence for implication of direct selection panicle length, biological yield per plant, harvest index and test weight should be considered for grain yield improvement.

\section{References}

Arunachalam, V., (1981). Genetic divergence in plant breeding. Indian J. Genet., (14): 226-236.

Basavaraja, P., Rudraradhya, M. and Kulkarni, R. S. (1997). Genetic variability, correlation and path analysis of yield components in two F4 population of five rainfed. Mysore $J$. Agric. Sci., 31: 1-6.

Chakraborty, S., Das, P. K.., Guha, B., Barman, B. and Sarmah, K. K. (2001). Coheritability, correlation path analysis of yield components in boro rice. Oryza, 38: 99-101.

Chaudhary, R.R., Joshi BK (2005). Correlation and Path Coefficient Analyses in Sugarcane. Nepal Agric. Res. J., 6: 24-28.

Deepa Sankar, P., Sheeba, A and Anbumalarmathi, J. (2006). Variability and character association studies in rice. Agric. Sci. Digest. 26 (3): 182-184.

Dewey, D.R., Lu, K.H., (1959). A correlation and path coefficient analysis of components of crested wheatgrass seed production. Agron. J., 51: 515-518.

Ghosh, M. Pal, A.K. Pal, S.K. De, D.K., (2003) Relationship of leaf area and chlorophyll content with yield of aromatic rice. Agris J.,

Griffing, B. and Lindstorm, E.W. (1954). A study of the combining ability of corn hybrids having varying proportions of corn bett and non-corn bett germplasm. Agron. J., 26: 545-552.

Mall, R.N., Sathwana, W.S. and Robinson, H.R. (1962). Heterosis and genetic diversity in varietal crosses of maize. Crop Sci., (2): 197-198.

Nayak, A.R., Chaudhury, D. and Reddy J.N. (2001).Correlation and path analysis in scented rice (Oryza satna L.) Indian J. Agric. Res., 35 (3): 186 - 189.

Padmaja, D., Radhika, K., Rao, L.V.S and Padma, V. (2011). Correlation and path analysis in rice germplasm. Oryza. 48 (1): 69-72.

Rao, C.R. (1952). Advanced Statistical Methods in Biometrical Research. John Wiley and Sons Inc., New Yark. 236272.

Rao, V.R., Hodgkin T (2002). Genetic diversity and conservation of plant genetic resources. Plant cell, Tissue and Organ Culture 68, 1-9

Ravindra Babu, V., Shreya, K., Kuldeep Singh Dangi, Usharani, $G$ and Siva Shankar, A. (2012). Correlation and 
path analysis studies in popular rice hybrids of India. International Journal of Scientific and Research Publications. 2 (3): 1-5.

Sankar, P.D., Sheeba, A and Anbumalarnathi, J. (2006). Variability and character association studies in rice (Oryza sativa L.). Agricultural Science Digest. 26 (3): 182-184.
Sarawgi, A. K., Rastogi, N. K. and Soni, D.K. (1997): Correlation and path analysis in rice accessions from Madhya Pradesh. Field Crops Research. 52(1): 161-167

Suman, A. (2003). Studies on genetic diversity and agro-morphological characterization of rice (Oryza sativa L.) germplasm. M.Sc. (Ag.) Thesis, Acharya N.G. Ranga Agricultural University, Hyderabad.

\section{How to cite this article:}

Chandan Kishore, Anil Kumar, Awadhesh K. Pal, Vinod Kumar, B.D. Prasad and Anand Kumar. 2018. Character Association and Path Analysis for Yield Components in Traditional Rice (Oryza sativa L.) Genotypes. Int.J.Curr.Microbiol.App.Sci. 7(03): 283-291. doi: https://doi.org/10.20546/ijcmas.2018.703.033 